\title{
The phytochemistry of Cymbopogon winterianus essential oil from Lombok Island, Indonesia and its antifungal activity against phytopathogenic fungi
}

\author{
PUTRI SRI ANDILA ${ }^{1, \bullet}$, I PUTU AGUS HENDRA ${ }^{1}$, PUTRI KESUMA WARDANI ${ }^{1}$, I GEDE TIRTA ${ }^{1}$, SUTOMO $^{1}$, \\ DEDEN FARDENAN ${ }^{2}$ \\ 1“Eka Karya” Bali Botanic Gardens, Indonesian Institute of Sciences. Candikuning, Baturiti, Tabanan 82191, Bali, Indonesia. Tel.: +62-368-2033211, \\ Fax. +62-368-2033171, `email: putribot11@gmail.com \\ ${ }^{2}$ Assessment Institute for Agricultural Technology, Agricultural Research and Development Agency. Pontianak 78061, West Kalimantan, Indonesia
}

Manuscript received: 20 August 2018. Revision accepted: 14 October 2018.

\begin{abstract}
Andila PS, Hendra IPA, Wardani PK, Tirta IG, Sutomo, Fardenan D. 2018. The phytochemistry of Cymbopogon winterianus essential oil from Lombok Island, Indonesia and its antifungal activity against phytopathogenic fungi. Nusantara Bioscience 10: 232239. Cymbopogon winterianus Jowitt ex Bor [Sereh Wangi] is a plant producing essential oil that has been extensively used in perfumery, mosquito repellent, medicinal, and cosmetic industry. In Indonesia, the accession of $C$. winterianus plant had been collected from natural forest in Sembalun, Lombok, West Nusa Tenggara (NTB) Province. However, the phytochemical properties and its biological potential of this accession have never been reported. The aim of this study was to determine the phytochemical content of essential oil of $C$. winterianus from Lombok and to explore its potential as a bioantifungal against several phytopathogen fungi. The essential oils were extracted from fresh stem and leaf of $C$. winterianus by hydrodistillation. The chemical composition of them was determined by chromatography-mass spectrometry (GC-MS). A total of 26 and 20 compounds were obtained from the stem and leaf oil with the dominant compounds of essential oil in stem were Torreyol (17.89\%), Oxirane, octyl- (15.84\%), (-)-Isopulegol (14.44\%), Isopulegol 2 (12.18\%), and Geranyl Acetate (5.89\%) while in leaf were (-)-Isopulegol (22.69\%), Oxirane, octyl- (16.64\%), Cyclohexanol, 5-methyl-2-(1-methylethenyl)- (14.21\%), "KW3 AUS Epiglobulol" (9.47\%), and Cyclohexene, 1-methyl-4-(1methylethenyl)- (7.14\%). The presence of these contents as dominant chemical compounds in S. winterianus was reported for the first time. The highest content of oils was identified as monoterpene (38.01\% and $45.78 \%$ in stem and leaf oil) and sesquiterpene ( $27.67 \%$ and $17.78 \%$ in stem and Leaf oil). The biological study showed that leaf essential of $C$. winterianus expressed positive antifungal activity against Fusarium solani, Aspergillus niger, dan Cladosporium sp.
\end{abstract}

Keywords: Hydrodistillation, GC-MS, leaf oil, phytochemical, stem oil

\section{INTRODUCTION}

Cymbopogon is an aromatic perennial herb of the Poaceae family, with the height up to and above $1 \mathrm{~m}$ with leaf shape showing narrow and long green. Cymbopogon consists of more than 144 species, and It is widely distributed in the tropical and subtropical regions of Africa, Asia, and America (Avoseh et al. 2015). Traditionally, several Cymbopogon species are used for various purposes in different countries, such as flavouring agent (Bhattacharya 2016), medicinal purposes as diuretics and treating gastrointestinal disorders (Hasim et al. 2017), antiinflammatory, analgesic, flu control, antioxidant, antiseptics, malaria therapy, and also to cure rheumatism and fever (Avoseh et al. 2015).

Several bioassays have shown pharmacological evidence of some Cymbopogon species. C. citratus was found to express pharmacologic effects as cytotoxicity (Kpoviessi et al. 2014), insecticidal (Pinto et al. 2013), antitrypanosomal (Kpoviessi et al. 2014), anti-diabetic (Bharti et al. 2013), antihypertensive (Dzeufiet et al. 2014), antioxidant (Somparn et al. 2014), anti-inflammatory (Tavares et al. 2015), hepatoprotective (Rahim et al. 2014), antifungal (Amornvit et al. 2014), and antimalaria (Chukwuocha et al. 2016). Biological assay of C. martinii extracts revealed a potential of this species as a strong antioxidant (Andrade et al. 2014a), and anti-inflammatory (Andrade et al. 2014b). C. flexuosus showed positive activities as antibiofilm against rapidly growing mycobacteria (Rossi et al. 2017), mosquito repellent (Carreño Otero et al. 2018), and anti-inflammatory (Han and Parker 2017). C. schoenanthus exhibited positive anticancer activity by promoting melanogenesis in B16 melanoma cells and human epidermal melanocytes (Villareal et al. 2017) and positive antibacterial activities against Escherichia coli, Staphylococcus aureus, methicillin-sensitive (MSSA) and Klebsiella pneumoniae ( Hashim et al. 2017). C. flexuosus had potential as an antiinflammatory (Han and Parker 2017) and antimicrobial activity (Adukwu et al. 2016). While C. nardus was reported for representing positive antifungal activities against Candida albicans (Trindade et al. 2015, Kandimalla et al. 2016; De Toledo et al. 2016) and Microsporum canis (Capoci et al. 2015), as a mosquito repellent (Ilahi and Yousafzai 2017). C. jwarancusa was found to have a flukicidal activity which used as alternative 
sources of treatment for trematodes infection (Shafiq et al. 2015). C. validus (Stapf) Stapf ex Burtt Davy had potential as an anti-inflammatory (Rungqu et al. 2016), and $C$. winterianus was found exhibiting potential as a mosquito repellent, bioinsecticide (Deletre et al. 2015; Sajo et al. 2015; Silva et al. 2018), and as an orofacial antinociceptive (Santos et al. 2015).

Cymbopogon winterianus locally called "Sereh Wangi" (Java, Bali, Lombok) is a member of genus Cymbopogon with wide distribution area. This plant had been used traditionally in several countries in the world, such as Brazil, India, and Southeast Asia (Avoseh et al. 2015). The pharmacological study confirmed that this species had enormous potency as Molucidal, Larvicidal (Rodrigues et al. 2013), and as an antifungal against Candida albicans (Cavalcanti et al. 2017). C. winterianus contains various plant metabolites such as Geraniol, Citronellal, Citronellol (Rodrigues et al. 2013) Linalool and Camphene (Wany et al. 2013) with have potential for various purpose, including as bio-fungicidal agent. In Indonesia, traditionally, this species has been used for many purposes, such as treatment for various diseases, mosquito repellent, and as a flavoring agent, but the information about its phytochemical properties and its biological function, especially as an antifungal agent was still limited. The aim of this study was to explore the phytochemical composition of $C$. winterianus essential oil collected from Sembalun, Lombok Island, Indonesia and to investigate its biofungicide potential against plant pathogenic fungi.

\section{MATERIALS AND METHODS}

\section{Study area}

Sampling sites of $C$. winterianus are in the natural forest of Sembalun Sub-district, East Lombok District (Lombok Island), West Nusa Tenggara Province, Indonesia.

\section{Plant material and sample preparation}

Cymbopogon winterianus was obtained from plants collection of "Eka Karya"-Bali Botanic Garden in March 2017. This plant was collected from natural forest in Sembalun, Lombok Island, West Nusa Tenggara in 2014,

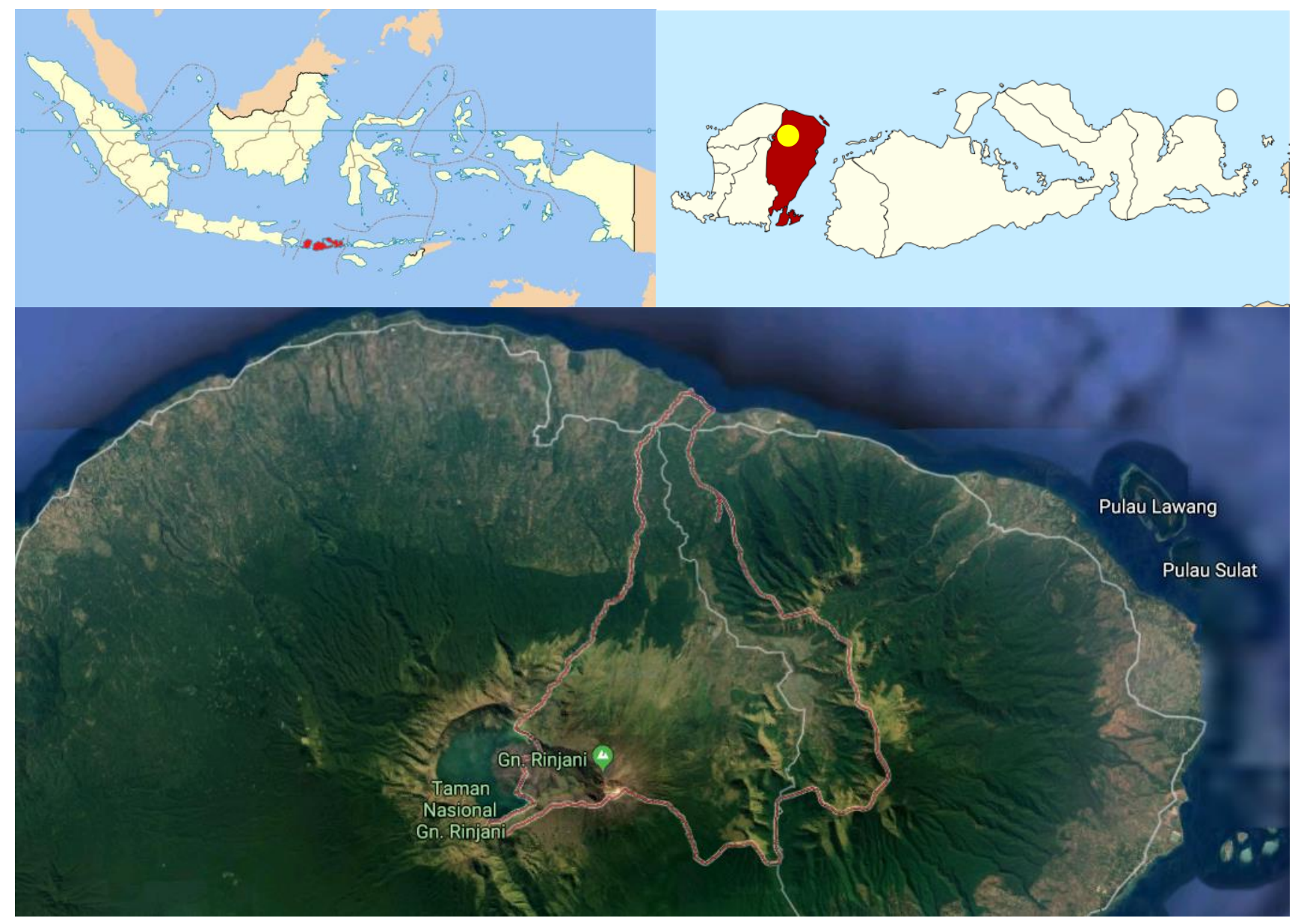

Figure 1. Location of natural forest in Sembalun, Lombok Island, West Nusa Tenggara, Indonesia indicating the sampling sites of Cymbopogon winterianus 
and planted at Bali Botanic Garden in 2015. Bali Botanical Garden was located in dry highland in the Bedugul Region, North Bali with temperature ranging between $18-20^{\circ} \mathrm{C}, 70$ $90 \%$ humidity and altitude of $1250-1450 \mathrm{~m}$ above sea level ( (Peneng and Andila 2017). The plant was identified by a taxonomist of Bali Botanic Garden, Ida Bagus Ketut Arinasa, of 56 herbaria of this species were deposited in Herbarium of Tabanan Hortus Botanicus Baliense (THBB). Fresh materials (stems and leaves) of $C$. winterianus were chopped and dried without direct sun irradiance for several days until the materials were completely dry.

\section{Isolation of essential oil}

Two hundred gram dry material of $C$. winterianus was extracted by hydrodistillation for five hours using a Pudak Scientific apparatus. The essential oil was separated by a Duran Schott separator and produced a yellowish viscous essential oil.

\section{Determination of Extraction Yield (\% yield)}

The essential oil yielded (\%, w/w) from all dry materials was calculated according to modification of Negreiros et al. (2015) method, as follows:

$$
\text { Yield }(\%)=\frac{W 1 \times 100}{W 2}
$$

Where $\mathrm{W} 1$ is the weight of the essential oil after hydrodistillation, and W2 is the weight of the fresh plant material.

\section{GC-MS analytical conditions and Identification of essential oil component}

The chemical components of $C$. winterianus essential oil were analyzed using GC-MS equipment model Shimadzu GC-MS-QP2010 with an Rtx 5ms capillary column (60.0 m x $25 \mathrm{~mm}$ with $0.25 \mu \mathrm{m}$ thickness). Carrier gas was UHP Helium with the conditions of GC setting was column oven at temperature of $50{ }^{\circ} \mathrm{C}( \pm 5$ minutes to $280^{\circ} \mathrm{C}$, injection temperature at $280^{\circ} \mathrm{C}$, injection mode: split, total program time: 50 minute, flow control mode : Linear velocity, pressure : $101.0 \mathrm{KPa}$, Total Flow : 46.5 mL/Min, Column Flow: $0.85 \mathrm{~mL} / \mathrm{min}$, linear velocity: 23.7 $\mathrm{cm} / \mathrm{sec}$, purge flow : $3.0 \mathrm{ml} / \mathrm{min}$, split ratio : 1 : 50 ,total sample injection : $1 \mu \mathrm{L}$. The MS settings were ion source temperature: $200^{\circ} \mathrm{C}$, interface temperature: $280^{\circ} \mathrm{C}$, solvent cut time: $1.5 \mathrm{~min}$, and detector temperature $280^{\circ} \mathrm{C}$.

Mass spectra fragmentation patterns identified the compounds. Identities of compounds were approved by comparing each retention time indices and the spectral data with those from computer library WILEY7.LIB and freepublished literature.

\section{Antifungal assay}

The antifungal assay of $C$. winterianus essential oil was carried out by the disc diffusion assay method (Diánez et al. 2018). Four plant pathogenic fungi obtained from the Laboratory of Mycology, Udayana University, Fusarium solani, Aspergillus niger, Colletotrichum sp. were used for the antifungal assay. The Fungi cultures collection were stored on an agar slant of Difco TM Potatoe Dextrose Agar at $40^{\circ} \mathrm{C}$ and re-grown every two months. The mature fungi cultures (about 7 days of incubation) on agar slant were diluted in sterile distilled water to obtain the spores fro experiment (Broekaert et al. 1990). The sporangial suspension $(1 \mathrm{~mL})$ was inoculated into petri disc, poured with dilute PDA (medium temperature of about $45-50^{\circ} \mathrm{C}$ ), and homogenized. The plates were left for 40 minutes at temperature of $27^{\circ} \mathrm{C}$ to allow the mixture of PDA and spores to compact. Afterward, one paper disc (Whatman paper disc with $6 \mathrm{~mm}$ in diameter) were put on the center of PDA plate surface, and impregnated with $20 \mu \mathrm{l}$ of the fruit essential oil of $Z$. avicennae (0-5\% concentration). Petri dishes were incubated at room temperature around 27$30^{\circ} \mathrm{C}$ for $24-48$ hours and the antifungal activity was observed by measuring minimal inhibitory concentration (MIC) (Kacem et al. 2016). MIC is the lowest concentration of essential oil, which inhibits the visible growth of plant pathogenic fungi during the incubation period. These treatments were carried out in triplicate. The antifungal activity was determined by the formation of a clear zone around the paper discs as an antifungal activity indicator (after 48-72 hours of incubation). A paper disc impregnated with acetone was served as the negative control.

\section{RESULTS AND DISCUSSION}

The essential oil extracted from aerial parts (stem and leaf) of $C$. winterianus yielded $0.6-0.67 \%(\mathrm{w} / \mathrm{w})$. A total of 26 and 20 volatile substances were identified in the stem and leave essential oil of $C$. winterianus, accounting for $97.4 \%$ and $94.5 \%$ of the oil. The identified phytochemical components and their relative concentration were summarized in Table 1 and Table 2. While the GC-MS chromatograms were performed in Figure 2.

As shown in Table 1, the major components found in the stem essential oil of $C$. winterianus in the present study were Torreyol (17.89\%), Oxirane, octyl- (15.84\%), (-)Isopulegol (14.44\%), Isopulegol 2 (12.18\%), and Geranyl Acetate $(5.89 \%)$. While the main compounds of essential oil of $C$. winterianus leaf (Table 2) were Isopulegol (22.69\%), Oxirane, octyl- (16.64\%), Cyclohexanol, 5methyl-2-(1-methylethenyl)- (14.21\%), "KW3 AUS Epiglobulol" (9.47\%), and Cyclohexene, 1-methyl-4-(1methylethenyl)- (7.14\%). In this species, a high amount of terpenoids were identified as dominant compounds with details $67.45 \%$ of the total stem oil and $71.12 \%$ of the total leaf oil. The volatile oil of $S$. winterianus stem consisted of monoterpene $38.01 \%$, sesquiterpene $27.67 \%$, and another terpene $1.18 \%$. Whereas, the leave essential oil comprised monoterpene $45.78 \%$, sesquiterpene $17.78 \%$, and another terpene $7.14 \%$. 
Table 1. The result of GCMS analyses obtained from essential oil of Cymbopogon winterianus Jowitt ex Bor stem
Table 2. The result of GCMS analyses obtained from essential oil of Cymbopogon winterianus Jowitt ex Bor leaf

\begin{tabular}{|c|c|c|c|c|c|c|c|}
\hline Peak & Name & $\begin{array}{l}\text { R. } \\
\text { time }\end{array}$ & $\begin{array}{l}\text { Relative } \\
\text { conc\% }\end{array}$ & Peak & Name & $\begin{array}{l}\text { R. } \\
\text { time }\end{array}$ & $\begin{array}{c}\text { Relative } \\
\text { conc\% }\end{array}$ \\
\hline 1 & 1,1-dimethyl diborane-D6 & 3.298 & 5.76 & 1 & Cyclohexene, 1-methyl-4-(1- & 11.976 & 7.14 \\
\hline 2 & 1-P-mentha-1,8-diene & 11.968 & 0.77 & & methylethenyl)- & & \\
\hline 3 & Alpha.-Terpinolene & 12.950 & 0.41 & 2 & Alpha.-Terpinolene & 12.939 & 0.63 \\
\hline 4 & (-)-Isopulegol & 13.663 & 14.44 & 3 & (-)-Isopulegol & 13.646 & 22.69 \\
\hline 5 & Oxirane, octyl- & 14.529 & 15.84 & 4 & Oxirane, octyl- & 14.454 & 16.64 \\
\hline 6 & Isopulegol 2 & 14.821 & 12.18 & 5 & Cyclohexanol, 5-methyl-2-(1- & 14.754 & 14.21 \\
\hline 7 & Z-Citral & 14.932 & 0.82 & & methylethenyl)- & & \\
\hline 8 & Citronellyl acetate & 15.550 & 4.68 & 6 & Z-Citral & 14.906 & 1.16 \\
\hline 9 & Geranyl Acetate & 15.830 & 5.89 & 7 & Citronellyl acetate & 15.511 & 3.55 \\
\hline \multirow[t]{2}{*}{10} & Cyclohexane, 1-ethenyl-1-methyl- & 16.062 & 1.48 & 8 & Geranyl acetate & 15.803 & 2.13 \\
\hline & 2,4-bis (1-methylethenyl)- & & & 9 & Eugenol & 15.867 & 1.41 \\
\hline 11 & Germacrene D & 16.954 & 1.54 & 10 & 2,4-diisopropenyl-1-methyl-1-vinyl- & 16.049 & 1.00 \\
\hline 12 & alpha.-Muurolene & 17.031 & 0.47 & & cyclohexane & & \\
\hline 13 & Spathulenol & 17.082 & 0.41 & 11 & Germacrene D & 16.946 & 1.12 \\
\hline 14 & Elemol & 17.282 & 4.95 & 12 & delta.-Cadinene & 17.207 & 1.63 \\
\hline 15 & Torreyol & 18.341 & 17.89 & 13 & Elemol & 17.276 & 0.47 \\
\hline 16 & Farnesol & 18.710 & 0.93 & 14 & "KW3 Aus Epiglobulol" & 17.538 & 9.47 \\
\hline 17 & $\begin{array}{l}\text { 7-Oxabicyclo[4.1.0]heptane, 1- } \\
\text { methyl-4-(2-methyloxiranyl)- }\end{array}$ & 19.628 & 0.30 & 15 & $\begin{array}{l}\text { Kauran-18-al, 17-(acetyloxy)-, } \\
\text { (4.beta.)- }\end{array}$ & 17.800 & 4.27 \\
\hline 18 & (-)-Spathulenol & 19.783 & 0.59 & 16 & Alpha.-Cadinol & 18.413 & 4.09 \\
\hline 19 & Palmitic acid & 20.292 & 0.78 & 17 & Nerolidol $\mathrm{Z}$ and $\mathrm{E}$ & 20.608 & 0.42 \\
\hline \multirow[t]{2}{*}{20} & Cyclopropanemethanol, 2-methyl-2- & 20.605 & 0.76 & 18 & Tricosane & 23.192 & 0.92 \\
\hline & (4-methyl-3-pentenyl)- & & & 19 & Pentatriacontane & 24.108 & 1.15 \\
\hline 21 & Tricosane & 21.674 & 0.84 & 20 & Heptacosane & 28.017 & 0.55 \\
\hline 22 & Docosane & 23.202 & 1.48 & & & & $94.65 \%$ \\
\hline 23 & Eicosane & 24.122 & 1.58 & & & & \\
\hline 24 & M-N-undecyl phenol & 24.445 & 0.39 & & Terpene & & $71.12 \%$ \\
\hline 25 & Pentatriacontane & 25.197 & 1.32 & & Monoterpene & & $45.78 \%$ \\
\hline \multirow[t]{6}{*}{26} & Hexatriacontane & 28.034 & 0.53 & & Sesquiterpene & & $17.78 \%$ \\
\hline & & & 97.03 & & Another terpene & & $7.14 \%$ \\
\hline & Terpene & & $67.45 \%$ & & & & \\
\hline & Monoterpene & & $38.01 \%$ & & & & \\
\hline & Sesquiterpene & & $27.67 \%$ & & & & \\
\hline & Another terpene & & $1.18 \%$ & & & & \\
\hline
\end{tabular}

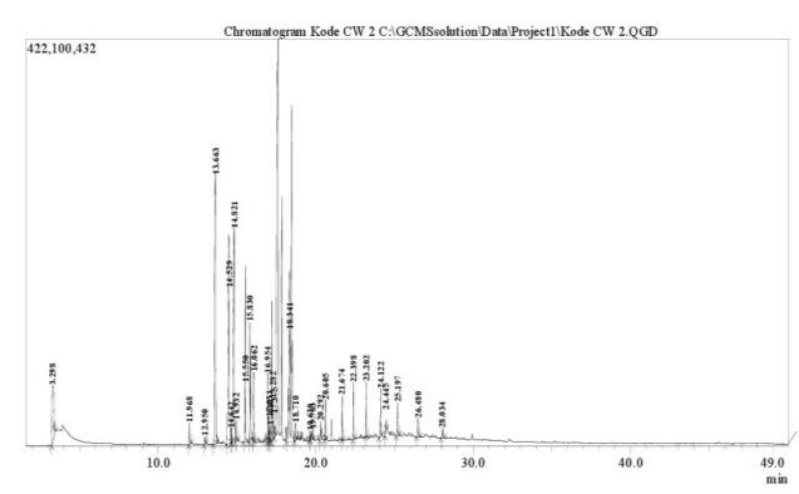

A

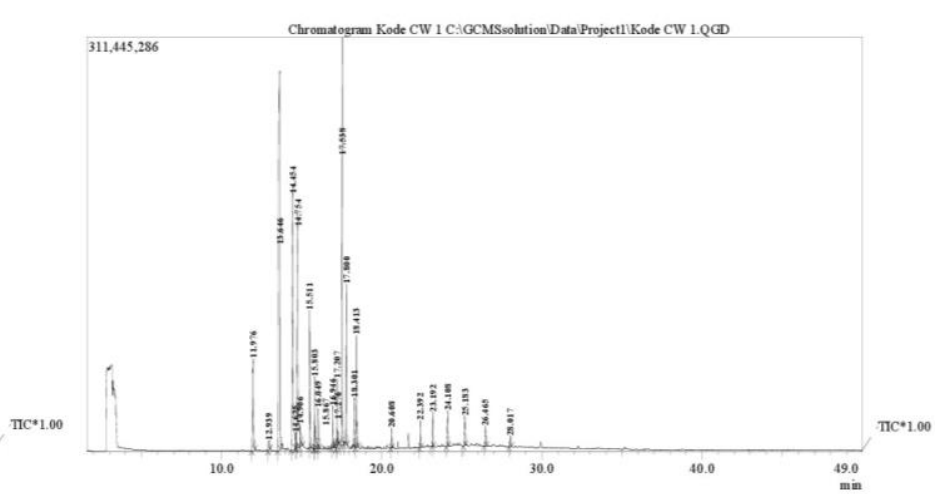

B

Figure 2. GC-MS chromatograms of the stem (A) and leaf (B) essential oil of Cymbopogon winterianus Jowitt ex Bor from Lombok, West Nusa Tenggara 
By comparing these results with previous studies, completely different chemical compositions were obtained. The presence of these contents as dominant chemical compounds in $S$. winterianus was reported for the first time. Previous research studies mentioned that the dominant contents of $S$. winterianus were citronella, citronellol, and geraniol (Quintas-Junior et al. 2008; Katiyar et al. 2011; Pinheiro et al. 2013). Several publications about phytochemical contents in $S$. winterianus was shown in Table 3.

Isopulegol is a monoterpene alcohol which is present in the essential oils of various plants. The existence of (-)Isopulegol in EO of $S$. winterianus had been reported by Quintas-Júnior et al. (2008), Pinheiro et al. (2013), and Kakaraparthi et al. (2014), but in low relative concentration (in concentration series of $0.60 \%, 1.53 \%$ and $0.30-0.50 \%$ ). Torreyol is classified as sesquiterpenoid alcohol produced by many plants, animal and microorganisms. The presence of Terreyol in the $S$. winterianus essential oils was also detected by Oliveira et al. (2011) and by Pinheiro et al. (2013) with relative concentration $1.65 \%$ and $1.44 \%$. Several compounds commonly existed in $C$. winterianus essential oil was also found in this present study, but in lower concentration, i.e. geranyl acetate $(5.89 \%$ in the stem
EO and $2.13 \%$ in the leaf EO, Citronellyl acetate $(4.68 \%$ in the stem EO and $3.55 \%$ in the leaf EO, Elemol $(4.95 \%$ in the stem EO and $0.47 \%$ in the leaf EO. The difference in the chemical composition of essential oils in a species of plant from different places is due to various factors among others such as differences of geographical location, season, and climate (Mahzooni-Kachapi et al. 2014; Shams et al. 2016; Sanli et al. 2017), genetic diversity (Purushothamhkjan and Ravi 2013), various of plant parts (stem, flower, fruit) (Faidi et al. 2014), and differences stage of plant growth (Flamini et al. 2013; Faidi et al. 2014) and other factors.

A study of the antifungal activity of essential oil compounds of $C$. winterianus against several plant pathogenic fungi was reported in Table 4. This study was conducted to observe the effect of variation of essential oil concentration towards Fusarium solani, Aspergillus niger, and Colletotrichum sp. The results showed that essential oil of $C$. winterianus expressed significant antifungal activity against Fusarium solani (MIC 3\% and inhibition zone 1.75 $\pm 0.21 \mathrm{~cm}$ ), Aspergillus niger (MIC $0.25 \%$ with inhibiting zone $1.67 \pm 0.39 \mathrm{~cm}$ ), and Colletotrichum sp. (MIC 1\% with inhibit zone $1.75 \pm 0.22 \mathrm{~cm}$ ).

Table 3. The results of major phytochemical contents in $S$. winterianus essential oil base on the previous literature

\begin{tabular}{|c|c|c|c|c|c|}
\hline No. & Species & Material & Dominant compounds & Origin & Literature \\
\hline 1 & S. winterianus & $\begin{array}{l}\text { The fresh material } \\
\text { of leaves }\end{array}$ & $\begin{array}{l}\text { Geraniol }(28.62 \%) \text {, citronellal } \\
(23.62 \%) \text {, citronellol }(17.10 \%)\end{array}$ & $\begin{array}{l}\text { Espírito Santo State, Brazil (an } \\
\text { altitude of } 250 \mathrm{~m} \text {.) }\end{array}$ & $\begin{array}{l}\text { (Pinheiro et al. } \\
\text { 2013) }\end{array}$ \\
\hline 2 & S. winterianus & $\begin{array}{l}\text { The oven-dried } \\
\text { material of leaves }\end{array}$ & $\begin{array}{l}\text { geraniol }(40.06 \%) \text {, citronellal } \\
(27.44 \%) \text {, citronellol }(10.45 \%)\end{array}$ & $\begin{array}{l}\text { at the Research Station "Campus } \\
\text { Rural da UFS" of the Universidade } \\
\text { Federal de Sergipe, Brazil }\end{array}$ & $\begin{array}{l}\text { (Quintans- } \\
\text { Junior et al. } \\
\text { 2008) }\end{array}$ \\
\hline 3 & S. winterianus & Not mentioned & $\begin{array}{l}\text { citronellal (31.1-35.4\%), geraniol } \\
(22.4-30.2 \%) \text {, citronellol (7.4- } \\
11.0 \%)\end{array}$ & $\begin{array}{l}\text { Andhra, Pradesh, Assam, Gujarat, } \\
\text { Jammu and Kashmir, Tamilnadu, } \\
\text { Uttar Pradesh and Uttarakhand } \\
\text { (India) }\end{array}$ & $\begin{array}{l}\text { (Wany et al. } \\
\text { 2013) }\end{array}$ \\
\hline 4 & S. winterianus & Not mentioned & $\begin{array}{l}\text { geraniol }(50.1 \%), \text { citral }(21.8 \%), \\
\text { citronellal }(11.8 \%)\end{array}$ & $\begin{array}{l}\text { Southern and northern sub- } \\
\text { Himalayan region of India }\end{array}$ & $\begin{array}{l}\text { (Wany et al. } \\
\text { 2013) }\end{array}$ \\
\hline 5 & S. winterianus & $\begin{array}{l}\text { The fresh material } \\
\text { of the aerial part of } \\
\text { plants }\end{array}$ & $\begin{array}{l}\text { citronellal }(35.9 \%) \text {, geraniol } \\
(20.9 \%)\end{array}$ & $\begin{array}{l}\text { Viamão in the state of Rio Grande do } \\
\text { Sul, in Southern Brazil. }\end{array}$ & $\begin{array}{l}\text { (Cassel and } \\
\text { Vargas 2006) }\end{array}$ \\
\hline 6 & S. winterianus & $\begin{array}{l}\text { The fresh material } \\
\text { of leaves }\end{array}$ & $\begin{array}{l}\text { citronellal }(29.15 \%) \text {, geraniol } \\
(22.52 \%) \text {, citronellol }(7.43 \%)\end{array}$ & Kanpur, India & $\begin{array}{l}\text { (Singh and } \\
\text { Kumar 2017). }\end{array}$ \\
\hline 7 & S. winterianus & $\begin{array}{l}\text { The air-dried } \\
\text { material of leaves }\end{array}$ & $\begin{array}{l}\text { citronellal (26.5\%), geraniol } \\
(16.2 \%) \text {, elemol }(14.5 \%), \\
\text { citronellol }(7.3 \%)\end{array}$ & Sao Lu1s, Maranhao, Brazil & $\begin{array}{l}\text { (Rodrigues et } \\
\text { al. 2013) }\end{array}$ \\
\hline 8 & S. winterianus & $\begin{array}{l}\text { The fresh material } \\
\text { of the aerial part of } \\
\text { plants }\end{array}$ & $\begin{array}{l}\text { citronellal }(24-34.2 \%) \text {, geraniol } \\
(16.4-33.3 \%) \text {, geranylacetate } \\
(2.2-16.0 \%) \text {, citronellol }(4.5- \\
12.5 \%) \text {, elemol }(2.6-9.5 \%)\end{array}$ & Hyderabad, Andhra Pradesh, India. & $\begin{array}{l}\text { (Kakaraparthi } \\
\text { et al. 2014) }\end{array}$ \\
\hline 9 & S. winterianus & $\begin{array}{l}\text { The fresh material } \\
\text { of leaves }\end{array}$ & $\begin{array}{l}\text { linalool }(27.4 \%) \text {, citronellol } \\
(10.9 \%) \text {, geraniol }(8.5 \%)\end{array}$ & $\begin{array}{l}\text { at the slopes of Usambara mountains } \\
\text { in Mombo, Tanzania }\end{array}$ & $\begin{array}{l}\text { (Malele et al. } \\
\text { 2007) }\end{array}$ \\
\hline 10 & S. winterianus & Not mentioned & $\begin{array}{l}\text { citronellal }(23.59 \%) \text {, geraniol } \\
(18.81 \%) \text {, citronellol }(11.74 \%)\end{array}$ & $\begin{array}{l}\text { Brazil (Specific place was not } \\
\text { mentioned) }\end{array}$ & $\begin{array}{l}\text { (Oliveira et al. } \\
\text { 2011) }\end{array}$ \\
\hline
\end{tabular}


Table 4. The result of the antifungal activity of the leaf essential oil of $C$. winterianus [Sereh Wangi] from Lombok Island against plant phytopathogenic fungi

\begin{tabular}{|c|c|c|c|c|}
\hline \multirow{2}{*}{$\begin{array}{l}\text { Concentration } \\
\% \text { EOL of } C \text {. } \\
\text { winterianus }\end{array}$} & \multicolumn{4}{|c|}{$\begin{array}{l}\text { Inhibition zone of EOL versus plant phytopathogenic } \\
\text { fungi }(\mathrm{cm})\end{array}$} \\
\hline & $\begin{array}{c}\text { Fusarium } \\
\text { solani }\end{array}$ & $\begin{array}{l}\text { Aspergilus } \\
\text { niger }\end{array}$ & $\begin{array}{l}\text { Cladosporium } \\
\text { sp. }\end{array}$ & $\begin{array}{c}\text { Control } \\
\text { (Aceton) }\end{array}$ \\
\hline 5 & $2.67 \pm 0.18$ & NG & $2.17 \pm 0.28$ & - \\
\hline 3 & $1.75 \pm 0.21^{*}$ & $3.43 \pm 0.48$ & $1.73 \pm 0.13$ & - \\
\hline 1 & - & $1.98 \pm 0.20$ & $1.75 \pm 0.22^{*}$ & - \\
\hline 0.5 & - & $1.80 \pm 0.03$ & - & - \\
\hline 0.25 & - & $1.67 \pm 0.39^{*}$ & - & - \\
\hline 0.125 & - & - & - & - \\
\hline
\end{tabular}

Note: NG stands for "Not Growing" mean that there was no pathogen fungal growing in PDA media at all. * means that the inhibitory zone formed on the MIC (the minimum inhibitory concentration)

This is an encouraging result showing that essential oil of $C$. winterianus has potential as a bio-fungicide agent. Plant pathogenic fungi play an important role in the success of agricultural production in terms of both qualitative and quantitative yields. It had been predicted that the inability to control plant fungal disease has caused the disadvantage in agricultural fields reaching millions of dollars per year (Shuping and Eloff 2017). Several fungal diseases such as downy mildew and botrytis are difficult to eradicate, outbreaks of plant fungal diseases can continue to last several seasons, and have the potential to cause damage the horticultural crops (Wightwick et al. 2010). To control this damage, farmers have used chemical fungicides for years. The disadvantages of this approach are contamination of the environment (land, air, and water), potential human exposure to fungicide, and deposition of residue on the plants (crops, fruits).

Similarly, they have been the main cause of plant pathogenic fungi resistance (Sales et al. 2016). Due to these factors, adopting the plant extracts as biofungicide would be useful due to low toxicity to mammals, reduce the environmental exposure to synthetic chemical fungicides, and avoid the resistance effects (Seiber et al. 2014). To improve the resistance evolution control of plant pathogenic fungi, FRAC (Fungicide Resistance Action Committee) had given recommendations to use fungicides mixtures to broaden the spectrum of disease control or to make use of synergistic interactions leading to more potent fungal diseases control and higher flexibility. This recommendation is appropriate for the biofungicide action. Plant metabolite contains several antimicrobial compounds which can reduce the development of pathogens resistance due to the variation of the metabolic process (Shuping and Eloff 2017).

The research on the use of $C$. winterianus the fields of pharmacology, perfume, aromatherapy, and insect repellent has been widely studied, but the use of $C$. winterianus in biopesticides is still limited to be studied, especially as a biofungicide agent. Previous studies have reported that essential oil $C$. winterianus has insecticidal activity against Frankliniella schultzei and Myzus persicae (Pinheiro et al.
2013) and ethanol extract from $C$. winterianus are insecticidal to Tetranychus urtica (VicentiniI et al. 2015). In Thailand, the mixture of crude extract of leaves of $C$. winterianus and Azadirachta indica A.H.L. Juss. and rhizome of Alpinia galanga (L.) Wild. were used as bioinsecticide in vegetable and citrus orchard (Westphal and Jansen 1989). In this study, the screening of essential oil of C. winterianus as antifungal against plant pathogenic fungi is reported for the first time.

In the antifungal action of essential oil components, monoterpenes have taken an important role by inhibiting the fungal growth (Marei et al. 2018). The previous study showed that treatment of monoterpene inhibited the mycelial growth of several plant pathogenic fungi, including Rhizoctonia solani, Fusarium oxysporum, Penicillium digitatum, and Aspergillus niger which cause collar rot, fusarium wilt, green, and black mold, respectively (Marei et al. 2012). Other studies showed that A new monoterpene lactone has strong antifungal activity against Botrytis cinerea and Phytophthora nicotianae (Xu et al. 2016), Furthermore, carvacrol and thymol (phenolic monoterpenes) possessed fungicidal effects against Phytophthora capsici, P. nicotianae, Alternaria solani, Botrytis cinerea, F. oxysporum, Pyricularia grisea, Rhizoctonia solani, P. capsici, and P. nicotianae (Wang et al. 2018).

Based on the results of this study, it can be concluded that the essential oil of stem and leaves of C. winterianus from Sembalun, Lombok, West Nusa Tenggara, Indonesia have different composition due to their phytochemical contents compared with previous researches. The antifungal assay of its leaf essential oil exhibited biofungicidal potential against pathogen fungal $F$. solani, A. niger, and Cladosporium sp.

\section{ACKNOWLEDGEMENTS}

The authors would like to say thank to the essential oil research group at "Eka Karya" Bali Botanic Gardens, Bali, Indonesian Institute of Science for funding this research (DIPA-2016). We extend our high appreciation to Dr. Meity Proborini for providing facility to carryout antifungal study and sharing their opinion about the microbial context.

\section{REFERENCES}

Adukwu EC, Bowles M, Edwards-Jones V, Bone H. 2016. Antimicrobial activity, cytotoxicity and chemical analysis of lemongrass essential oil (Cymbopogon flexuosus) and pure citral. Appl Microbiol Biotechnol 100: 9619-9627.

Amornvit P, Choonharuangdej S, Srithavaj T. 2014. LemongrassIncorporated tissue conditioner against Candida albicans Culture. J Clin Diagn Res 8: ZC50-ZC52.

Andrade BFMT, Braga CP, Dos Santos KC, Barbosa LN, Rall VL, Sforcin JM, Fernandes AA, Fernandes Júnior A. 2014a. Effect of inhaling Cymbopogon martinii essential oil and geraniol on serum biochemistry parameters and oxidative stress in rats. Biochem Res Intl 2014: 1-7.

Andrade BFMT, Conti BJ, Santiago KB, Junior AF, Sforcin JM. 2014b. Cymbopogon martinii essential oil and geraniol at noncytotoxic 
concentrations exerted immunomodulatory/anti-inflammatory effects in human monocytes. J Pharm Pharmacol 66: 1491-1496.

Avoseh O, Oyedeji O, Rungqu P, Nkeh-Chungag B, Oyedeji A. 2015. Cymbopogon Species; Ethnopharmacology, Phytochemistry and the Pharmacological Importance. Molecules 20: 7438-7453.

Bharti SK, Kumar A, Prakash O, Krishnan S, Gupta AK. 2013. Essential oil of Cymbopogon citratus against diabetes: Validation by in vivo experiments and computational studies. J Bioanal Biomed 5: 194-203.

Bhattacharya S. 2016. Cultivation of essential oils. In Preedy VR (ed) Essential oils in food preservation, flavor and safety. Nikki levy, San Diago, USA.

Capoci IR, Cunha MM, Bonfim-Mendonça Pde S, Ghiraldi-Lopes LD Baeza LC, Kioshima ES, Svidzinski TI. 2015. Antifungal activity of Cymbopogon nardus (L.) Rendle (citronella) against Microsporum canis from animals and home environment. Rev Inst Med Trop Sao Paulo 57: 509-511.

Carreño-Otero AL, Palacio-Cortés AM, Navarro-Silva MA, Kouznetsov VV, Duque L JE. 2018. Behavior of detoxifying 8 enzymes of Aedes aegypti exposed to girgensohnine alkaloid analog and Cymbopogon flexuosus essential oil. Comp Biochem Physiol C Toxicol Pharmacol 204: 14-25.

Cassel E, Vargas RMF. 2006. Experiments and modeling of the Cymbopogon winterianus essential oil extraction by steam distillation. J Mex Chem Soc 50: 126-129.

Cavalcanti AL, Aguiar YPC, Santos FGD, Cavalcanti AFC, Dias De Castro R. 2017. Susceptibility of Candida albicans and Candida nonalbicans strains to essential oils. Biomed Pharmacol J 10: 1101-1107.

Chukwuocha UM, Fernández-Rivera O, Legorreta-Herrera M. 2016. Exploring the antimalarial potential of whole Cymbopogon citratus plant therapy. J Ethnopharmacol 193: 517-523.

De Toledo LG, Ramos MA, Spósito L, Castilho EM, Pavan FR, Lopes Éde O, Zocolo GJ, Silva FA, Soares TH, Dos Santos AG, Bauab TM, De Almeida MT. 2016. Essential oil of Cymbopogon nardus (L.) Rendle: A strategy to combat fungal infections caused by Candida species. Intl J Mol Sci 17: 1-16. DOI: 10.3390/ijms17081252.

Deletre E, Chandre F, Williams L, Duménil C, Menut C, Martin T. 2015 Electrophysiological and behavioral characterization of bioactive compounds of the Thymus vulgaris, Cymbopogon winterianus, Cuminum cyminum and Cinnamomum zeylanicum essential oils against Anopheles gambiae and prospects for their use as bednet treatments. Parasit Vectors 11: 1-14

Diánez F, Santos M, Parra C, Navarro MJ, Blanco R, Gea FJ. 2018. Screening of antifungal activity of twelve essential oils against eight pathogenic fungi of vegetables and mushroom. Lett Appl Microbiol 67: 400-410.

Dzeufiet PD, Mogueo A, Bilanda DC, Aboubakar BF, Tédong L, Dimo T, Kamtchouing P. 2014. Antihypertensive potential of the aqueous extract which combines leaf of Persea americana Mill. (Lauraceae), stems and leaf of Cymbopogon citratus (D.C) Stapf. (Poaceae), fruits of Citrus medical L. (Rutaceae) as well as honey in ethanol and sucrose experimental model. BMC Complement Altern Med 14: 1-12.

Faidi K, El Mokni R, Joshi RK, Hammami S, M'Henni MF, Mighri Z. 2014. Comparative study on the chemical constituents of essential oils from different organs of the Sicilian Kundmanni (Kundmannia sicula L.) DC. (Apiaceae) growing spontaneously in Tunisia. Nat Prod Res 28: $1680-1684$.

Flamini G, Smaili T, Zellagui A, Gherraf N, Cioni PL. 2013. Effect of growth stage on essential-oil yield and composition of Daucus sahariensis. Chem Biodivers 10: 2014-2020.

Han X, Parker TL. 2017. Lemongrass (Cymbopogon flexuosus) essentia oil demonstrated anti-inflammatory effect in pre-inflamed human dermal fibroblasts. Biochim Open 21: 107-111.

Hashim GM, Almasaudi SB, Azhar E, Al Jaouni SK, Harakeh S. 2017. Biological activity of Cymbopogon schoenanthus essential oil. Saudi J Biol Sci 24: 1458-1464.

Ilahi I, Yousafzai AM.. 2017. Larvicidal, pupicidal and adulticidal activities of non-polar solvent extract of Cymbopogon nardus (Linn.) whole plant against a mosquito, Culex quinquefasciatus (Say.). Pak J Pharm Sci 30: 2337-2340.

Kacem N, Roumy V, Duhal N, Merouane f, Neut C, Christen P, Hostettmann K, Rhouati S. 2016. Chemical composition of the essential oil from Algerian Genista quadriflora Munby and determination of its antibacterial and antifungal activities. Industr Crops Prod 90: 87-93.

Kakaraparthi PS, Srinivas KVNS, Kuma JK, Kumar AN, Rajput DK, Sarma VUM. 2014. Variation in the essential oil content and composition of Citronella (Cymbopogon winterianus Jowitt.) in relation to time of harvest and weather conditions. Ind Crops Prod 61: 240-248.

Kandimalla R, Kalita S, Choudhury B, Dash S, Kalita K, Kotoky J. 2016. Chemical composition and anti-candidiasis mediated wound healing property of Cymbopogon nardus essential oil on chronic diabetic wounds. Front Pharmacol 7: 1-8.

Kpoviessi S, Bero J, Agbani P, Gbaguidi F, Kpadonou-Kpoviessi B, Sinsin B, Accrombessi G, Frédérich M, Moudachirou M, QuetinLeclercq J. 2014. Chemical composition, cytotoxicity and in vitro antitrypanosomal and antiplasmodial activity of the essential oils of four Cymbopogon species from Benin. J Ethnopharmacol 151: 652659.

Leite BLS, Souza TT, Antoniolli AR, Guimarães AG, Siqueira RS, Quintans JSS, Bonjardim LR, Alves PB, Blank AF, Botelho MA, Almeida JRGS, Lima JT, Araújo AAS, Quintans-Júnior LJ. 2011. Volatile constituents and behavioral change induced by Cymbopogon winterianus leaf essential oil in rodents. Afr J Biotechnol 10: 83128319

Mahzooni-Kachapi SS, Mahdavi M, Jouri MH, Akbarzadeh M, RoozbehNasira'el NL. 2014. The effects of altitude on chemical compositions and function of essential oils in Stachys lavandulifolia Vahl. (Iran). Intl J Med Arom Plants 4: 107-116.

Malele RS, Mwangi JW, Thoithi GN, Kibwage IO, López ML, Zunino MP, López AG, Zygadlo JA, Oliva MM, Demo MS. 2007. Essential Oil of Cymbopogon winterianus Jowitt from Tanzania: composition and antimicrobial activity. J Essent Oil Bear Pl. 10: 83-87.

Marei GIKh, Abdelgalei SAM. 2018. Antifungal potential and biochemical effects of monoterpenes and phenylpropenes on plant pathogenic fungi. Plant Protect Sci 54: 1-8.

Marei, GIKh. Rasoul, MAA, Abdelgaleil SAM. 2012. Comparative antifungal activities and biochemical effects of monoterpenes on plant pathogenic fungi. Pesticide Biochem Physiol 103: 56-61.

Negreiros JRS, Miqueloni DP, Cartaxo CBC. 2015. Yield of essential oil and safrole content based on fresh and dry biomass of long pepper in the Brazilian Amazon. Acta Amazonica 45: 75-80.

Oliveira WA, Pereira FO, Luna GCDG, Lima IO, Wanderley PA, Lima RB, Lima EO. 2011. Antifungal activity of Cymbopogon winterianus Jowitt Ex Bor against Candida albicans. Braz J Microbiol 42: 433441.

Peneng IN, Andila PS. 2017. The Diversity of wild pepper plants in secondary forest of "Eka Karya" Botanic Garden, Candikuning Village, Baturiti, Tabanan, Bali. In: Septiasari A, Astuti A, Berlian IN, Kharismamurti K, Merdekawati NC, Alkarim YR (eds) Management of Biodiversity through the Biotechnology Application. Proceeding of National Seminary. Sebelas Maret University, Surakarta, 4 November 2016. [Indonesian]

Pinheiro PF, Queiroz VT, Rondelli VM, Costa AV, Marcelino TP, Pratissoli D. 2013. Insecticidal activity of citronella grass essential oil on Frankliniella schultzei and Myzus persicae. Ciênc agrotec. Lavras 37: 138-144.

Pinheiro PF, Tebaldi de Queiroz V, Rondelli VM, Costa AV, de Paula Marcelino T, Pratissoli D. 2013. Insecticidal activity of citronella grass essential oil on Frankliniella schultzei and Myzus persicae. Ciênc Agrotec Lavras 37: 138-144.

Pinto ZT, Sánchez FF, dos Santos AR, Ramos A, Amaral ACF, Ferreira JLP, Escalona-Arranz JC, de Carvalho Queiroz MM. 2015. Chemical composition and insecticidal activity of Cymbopogon citratus essential oil from Cuba and Brazil against housefly. Braz J Vet Parasitol Jaboticabal 24: 36-44.

Purushothaman DN, Ravi S. 2013. GC-MS analysis of essential oil obtained from Heracleum candolleanum (Wight et Arn). J Pharm Res 6: $155-157$.

Quintans-Junior LG, Souza TT, Leite BS, Lessa NMN, Bonjardim LR, Santos MRV, Alves PB, Blank AF, Antoniolli AR. 2008. Phytochemical screening and anticonvulsant activity of Cymbopogon winterianus Jowitt (Poaceae) leaf essential oil in rodents. Phytomedicine 15: 619-624.

Quintans-Júnior LJ, Souza TT, Leite BS, Lessa MN, Bonjardim LR, Santos MR, Alves PB, Blank AF, Antoniolli AR. 2008. Phytochemical screening and anticonvulsant activity of Cymbopogon winterianus Jowitt (Poaceae) leaf essential oil in rodents. Phytomedicine 15: 619-624.

Rahim SM, Taha EM, Al-Janabi MS, Al-Douri BI, Simon KD, Mazlan AG. 2014. Hepatoprotective effect of Cymbopogon citratus aqueous 
extract against hydrogen peroxide-induced liver injury in male rats. Afr J Tradit Complement Altern Med 11: 447-451.

Rodrigues KA, Dias CN, do Amaral FM, Moraes DF, Mouchrek Filho VE, Andrade EH, Maia JG. 2013. Molluscicidal and larvicidal activities and essential oil composition of Cymbopogon winterianus. Pharm Biol 51: 1293-1297.

Rodrigues KA, Dias CN, Moraes DF, Filho VM, Andrade EH, Mala J.G. 2013. Molluscicidal and larvicidal activities and essential oil composition of Cymbopogon winterianus. Pharm Biol 51: 1293-1297.

Rossi GG, Guterres KB, Bonez PC, da Silva Gundel S, Aggertt VA, Siqueira FS, Ourique AF, Wagnerd R, Klein B, Santos RCV, de Campos MMA. 2017. Antibiofilm activity of nanoemulsions of Cymbopogon flexuosus against rapidly growing mycobacteria. Microb Pathog 113: 335-341

Rungqu P, Oyedeji O, Nkeh-Chungag B, Songca S, Oluwafemi O, Oyedeji A. 2016. Anti-inflammatory activity of the essential oils of Cymbopogon validus (Stapf) Stapf ex Burtt Davy from Eastern Cape, South Africa. Asian Pac J Trop Med 9: 426-431.

Sajo ME, Song SB, Bajgai J, Kim YJ, Kim PS, Ahn DW, Khanal N, Lee KJ. 2015. Applicability of citronella oil (Cymbopogon winterianus) for the prevention of mosquito-borne diseases in the rural area of Tikapur, far-western Nepal. Rural Remote Health 15: 3532. https://www.ncbi.nlm.nih.gov/pubmed/26564331

Sales MDC, Costa HB, Fernandes PMB, Ventura JA, Meira DM. 2016. Antifungal activity of plant extracts with a potential to control plant pathogens in pineapple. Asian Pac J Trop Biomed 6: 26-31.

Şanli A, Karadoğan T. 2017. Geographical impact on essential oil composition of endemic Kundmannia anatolica Hub.-Mor. (Apiaceae). Afr J Tradit Compl Altern Med 14: 131-137.

Santos PL, Araújo AA, Quintans JS, Oliveira MG, Brito RG, Serafini MR, Menezes PP, Santos MR, Alves PB, de Lucca Júnior W, Blank AF, La Rocca V, Almeida RN, Quintans-Júnior LJ. 2015. Preparation, characterization, and pharmacological activity of Cymbopogon winterianus Jowitt ex Bor (Poaceae) leaf essential oil of $\beta$ cyclodextrin inclusion complexes. Evid Based Compl Altern Med 2015: 502454. DOI: $10.1155 / 2015 / 502454$.

Seiber JN, Coats J, Duke SO, Gross AD. 2014. Biopesticides: State of the art and future opportunities. J Agric Food Chem. 62: 11613 -11619.

Shafiq A, Kanwal R, Ullah Qureshi R, Riaz Chaudhry F. 2015. In vitro screening of Cymbopogon jwarancusa and Conyza canadensis against liver flukes. Trop Biomed 32: 407-412.

Shams M, Ramezani M, Esfahan SZ, Esfahan EZ, Dursun A, Yildirim E. 2016. Effects of climatic factors on the quantity of essential oil and dry matter yield of Coriander (Coriandrum sativum L.). Indian J Sci Technol 9: 1-4.
Shuping DSS, Eloff JN. 2017. The use of plants to protect plants and food against fungal pathogens: A Review. Afr J Tradit Compl Altern Med 14: $120-127$

Silva C, Wanderley-Teixeira V, Cunha FM, Oliveira JV, Dutra KA, Navarro DF, Teixeira A. 2018. Effects of citronella oil (Cymbopogon winterianus Jowitt ex Bor) on Spodoptera frugiperda (J. E. Smith) midgut and fat body. Biotech Histochem 93: 36-48.

Singh A, Kumar A. 2017. Cultivation of citronella (Cymbopogon winterianus) and evaluation of its essential oil, yield and chemical composition in Kannauj region. Intl J Biochem Biotechnol 13: 139146.

Somparn N, Saenthaweesuk S, Naowaboot J, Thaeomor A. 2014. Effects of Cymbopogon citratus Stapf water extract on rat antioxidant defense system. J Med Assoc Thai 97: S57-S63.

Tavares F, Costa G, Francisco V, Liberal J, Figueirinha A, Lopes MC, Cruz MT, Batista MT. 2015. Cymbopogon citratus industrial waste as a potential source of bioactive compounds. J Sci Food Agric 95 (13): 2652-2659.

Trindade LA, de Araújo Oliveira J, de Castro RD, de Oliveira Lima E. 2015. Inhibition of adherence of Candida albicans to dental implants and cover screws by Cymbopogon nardus essential oil and citronellal. Clin Oral Investig 19: 2223-2231.

VicentiniI VB, PratissoliI D, Tebaldi de QueirozII V, CostaII AV, PinheiroII PF, ZingerI FD, RondelliIII VM. 2015. Ethanol extract of Cymbopogon winterianus on mortality and number of eggs of Tetranychus urticae. Ciência Rural Santa Maria 45: 1154-1159.

Villareal MO, Kume S, Neffati M, Isoda H. 2017. Upregulation of mitf by phenolic compounds-rich Cymbopogon schoenanthus treatment promotes melanogenesis in B16 melanoma cells and human epidermal melanocytes. Biomed Res Intl 2017: 8303671. DOI: $10.1155 / 2017 / 8303671$

Wang K, Jiang S, Pu T, Fan L, Su F, Ye M. 2018. Antifungal activity of phenolic monoterpenes and structure-related compounds against plant pathogenic fungi. Nat Prod Res 15: 1-8. DOI: 10.1080/14786419.2017.1419232.

Wany A, Jha S, Nigam VK, Pandey DV. 2013. Chemical analysis and therapeutic uses of citronella oil from Cymbopogon winterianus: A short review. Intl J Adv Res 1: 504-521.

Westphal E, Jansen PCM. 1989. Plant Resources of South-East Asia. A selection. Pudoc, Wageningen, the Netherlands.

Wightwick A, Walters R, Allinson G, Reichman S, Menzies N. 2010. Environmental risks of fungicides used in horticultural production systems. In: Carisse O. (ed.). Fungicide. Intech, Rijeka, Croatia.

Xu D, Zhang BY, Yang XL. 2016. Antifungal monoterpene derivatives from the plant endophytic fungus Pestalotiopsis foedan. Chem Biodivers 13: 1422-1425. 